\title{
Too Much Too Soon? Common Core Math Standards in the Early Years
}

\author{
Laura Fricke Main
}

Published online: 29 September 2011

(C) Springer Science+Business Media, LLC 2011

\begin{abstract}
The author expresses concern about the math standards of the Common Core Curriculum in relation to young children. The editorial cites others who share concerns about how the global community uses standards. She suggests caution in implementation because the overemphasis on the standards may overlook the investment needed in effective curriculum development and professional development for teachers. The editorial concludes with the revisions will be neccesary to the current version of the Common Core Standards given the concern.
\end{abstract}

Keywords Common core - Standards - Young children · Curriculum · Professional development $\cdot$ Mathematics .

Kindergarten · Primary grades

The Common Core Math Standards have been written swiftly with a lofty implementation goal. The aim of the common core standards initiative is to have "fewer, clearer, higher standards" (Phillips and Wong 2010), yet the final document in its entirety is approximately 500 pages (Mathis 2010). While the standards have promise, there is much work to be done as a nation before we are ready to implement them, especially with our youngest students.

\section{The Revision Process}

A draft of the common core standards for mathematics was released on March 10, 2010 with a public comment period

L. F. Main $(\bowtie)$

Western Connecticut State University, Danbury, CT, USA

e-mail: main008@connect.wcsu.edu ending on April 2, 2010. At that point, the National Council for Teachers of Mathematics (NCTM) released a statement in support of the basic goals and aims of the initiative as well as having specific concerns (NCTM 2010). NCTM pointed out "a few serious placement issues" about the learning progressions being overambitious and beyond the bounds of what is knows from research (NCTM 2010). The position paper details examples of concerns including place value expectations in Kindergarten that would likely sacrifice understanding in a rush for rote responses as well as concerns about the term "the standard algorithm" when really it references the United States standard algorithm, which is one of many algorithms of which none is superior (NCTM 2010). Upon examination of the Common Core State Standards for Mathematics (CCSSO and NCA Center 2010), it does not appear as if these changes have been considered; however, the NCTM did endorse the final Common Core State Standards for Mathematics (Gewertz 2010) which was released in June, 2010.

\section{The Common Core Standards}

In the "Introduction to the Common Core State Standards", the Council of Chief State School Officers (CCSSO) and the National Governors Association Center for Best Practices (NGA Center) claim that the final version of the standards are the result of feedback from (a) the general public; (b) teachers; (c) parents; (d) business leaders; (e) states; and (f) content area experts, and that the standards themselves are informed by the standards of other high performing nations (CCSSO and NCA Center 2010). The Thomas B. Fordham Institute found that the academic standards in the common core are superior to the 
standards in 33 individual states (Carmichael et al. 2010). It seems that the word "informed" does not imply researchbased because, if the initiative continues at the same pace and is implemented nation-wide, it places the United States at risk of performing a high stakes national experiment on our students. This is especially of concern to our youngest students, who seem to have the most to lose if these standards are implemented as written.

\section{Investment in Standards}

In 2010, in a joint position paper issued on the Common Core Standards, The National Association for the Education of Young Children (NAEYC) and the National Association of Early Childhood Specialists in State Departments of Education (NAECS-SDE) makes a claim for the urgency of:

- Comprehensive curricula and assessments

- Professional development for teachers and administrators

- Resources

Even if the Common Core standards were superior, the standards alone are not sufficient for appropriate implementation. Early learning standards require effective curriculum, classroom practices, and teaching strategies that connect the interests and abilities of children and promote their development and learning (NAEYC 2002). Professional development is essential for early childhood teachers and administrators to gain the knowledge, skills and dispositions needed to implement early learning standards (NAEYC 2002). This is true of any new initiative, yet the rush to implement the Common Core as written seems to not account for this need. Darling-Hammond (2010) warns that it is important to invest not only in well-designed assessments, but also in teacher expertise (including professional development, instructional assistance, hiring and retention) and curriculum resources. It does not appear, at least at this time, that there is time for this important work to occur.

\section{The Promise of Standards}

Munson (2011), who is president and executive director of the nonprofit research organization Common Core, (a separate organization from the Common Core Standards), advocates for a renewed focus on content knowledge as opposed to overemphasis on skills alone. This position seems to take the stance of advocating for the Standards for Mathematical Practice over the Standards for Mathematical Content in the current Common Core Standards. The practice standards, as overarching principles, are powerful, yet when coupled with the details of the Content Standards in the current Common Core, may seem less important to practitioners. There is a line buried in the introduction to the Standards for Mathematical Practice which warns, "Designers of curricula, assessments, and professional development should all attend to the need to connect the mathematical practices to the mathematical content in mathematics instruction" (www.corestandards.org). While the Mathematical Practices emphasize understanding, it will take leadership at the state and local levels to emphasize these over the discrete standards which, on balance, lean more towards skill development.

Munson (2011) points out that the Common Core Standards are not curriculum in and of themselves and will mean little if implemented ineffectively. Reys and Lappan (2007) argue that in order to implement coherent, rigorous curriculum for all students, there is a need for leadership, cooperation and collaboration. Curriculum is needed for implementation and is another reason to delay implementation so that there is time to research, select and align local curricula appropriately.

NAEYC and NAECS-SDE (2010) agree that standards that are challenging, achievable, and appropriate to children's development are important for the success of every child. The question is not, "Should we have standards?" but instead, "Are the Common Core Standards, as written, appropriate?" It seems that there is more work to do and more discussions that need to occur before implementing the Common Core on a national scale.

\section{Criticism of the Common Core}

The development of the Common Core Standards was quick (approximately 1 year) with little input from school-based practitioners, yet in most standards efforts, there is both extensive practitioner involvement and public hearings conducted over the course of several years (Mathis 2010).

Mathis (2010) condemns the core standards with his claims that standards alone do not determine how well each state performs because those with high standards do no better (or worse) than those which have been identified as having low standards. Mathis (2010) also points out that very little evidence supports that having national academic standards will improve the quality of American public education and the push towards having these standards may pull the attention from other needed reforms in schools.

\section{International Comparisons}

Milgram (2010) condemns the Common Core Standards noting that there are "many serious flaws" (p. 3). He claims that he was not able to certify that the Common Core Mathematics Standards are benchmarked at the same 
level as standards of other high achieving countries (Milgram 2010).

The Trends in International Mathematics and Science Study (TIMSS) demonstrate that on eighth grade math and science tests, eight of the 10 top scoring countries had national standards, but so did 9 of the 10 lowest scoring countries in math (Kohn 2010). McCluskey (2010) points out that on the most recent TIMSS to include high school seniors, done in 1995, the United States finished poorly in the combined math and science literacy scale, fourth from the last. The three nations it outperformed all had national standards, but 3 out of the 5 top performing countries did not have national standards, including the top performer (McCluskey 2010). Another study found no correlation between the rigor of a particular state's standards and its National Association for Educational Progress (NAEP) scores (Whitehurst 2009).

The introduction to the Common Core State Standards claims that all research has been considered (http://www. corestandards.org/assets/ccssi-introduction.pdf), yet an example of a particular standard for young children that appears to lack a research base is the kindergarten place value standard:

Work with Numbers 11-19 to gain Foundations for Place Value.

K.NBT.1. Compose and decompose numbers from 11 to 19 into ten ones and some further ones, e.g., by using objects or drawings, and record each composition or decomposition by a drawing or equation (such as $18=10+8$ ); understand that these numbers are composed of ten ones and one, two, three, four, five, six, seven, eight, or nine ones.

This particular standard is repeated in first grade as well which makes it unclear why it is a kindergarten standard at all. The first grade place value standard is:

Understand Place Value.

1.NBT.2. Understand that the two digits of a twodigit number represents amounts of tens and ones. Understand the following as special cases:

a. 10 can be thought of as a bundle of ten ones- called a "ten."

b. The numbers from 11 to 19 are composed of ten and one, two, three, four, five, six, seven, eight or nine ones.

c. The numbers 10, 20, 30, 40, 50, 60, 70, 80, 90 refer to one, two, three, four, five, six, seven, eight or nine tens (and 0 ones).

It seems that these standards expect children to progress at an unprecedented rate through the primary years that seems to require our youngest students to make a leap that research out of Western Australia suggests that they are not ready to make developmentally. The research found that children enter what is called the partitioning phase between the ages 6 and 9 and by the end of this phase, usually between ages 9 and 11 , children can partition at least two and three digit numbers into parts (Western Australian Minister for Education 2006).While certainly some children in kindergarten and first grade can achieve these standards, is this truly achievable for all students even with the best curriculum and the best instruction? While a range of development is acknowledged by the writers of the Common Core in the introduction to the Common Core State Standards for Mathematics, the standards themselves are meant to "provide a consistent, clear understanding of what students are expected to learn" (http://www.corestandards.org). It seems as if there is more work to be done before making this claim. The introduction to the Common Core State Standards acknowledges that there is "more to be learned about the most essential knowledge for student success" (http:// www.corestandards.org), yet it appears we are forging forward without this full understanding.

\section{Standards and Assessment}

In all likelihood, the core standards will be accompanied by a national standardized test (Kohn 2010). Ravitch (2010), referring her $180^{\circ}$ turn on her position on No Child Left Behind (NCLB), states that the nations with successful school systems do not narrowly focus success in their schools on two skill-based subjects as measured by standardized test scores. Ravitch (2010) states that a good accountability system should include professional judgment and other measures of student achievement as opposed to simply test scores. She takes this one step further, warning that schools who expect only the basic skills from their students will not produce graduates who are college or workplace ready (Ravitch 2010). Her concern is that, by overemphasizing test scores to the exclusion of other goals, one may undermine both a love of learning and the desire to acquire knowledge, which are necessary for intrinsic motivation (Ravitch 2010). Mathis (2010) points out that the standards have not been field tested and that it is unclear whether the tests that will be used to measure the outcomes of the standards will have validity to justify the consequences that will likely arise.

\section{Standards and Young Children}

In a position statement, the National Association for the Education of Young Children (NAEYC) recognized the ethical responsibility to use standards; however it is unrealistic to expect that standards be fully implemented without the benefit of policies and funding that supports a system of high-quality developmentally appropriate 
experiences for all children (NAEYC 2009). In a joint position statement by NAEYC and the National Association of Early Childhood Specialists in the State Departments of Education (NAECS-SDE), the process of developing early learning standards should rely on expertise, stakeholder involvement and regular evaluation and review; the ways in which standards are developed and reviewed contribute to their credibility and effectiveness (NAEYC 2002).

In the joint position statement on the Common Core, NAEYC and NAECS-SDE (2010) remind that standards are not new to early childhood education, but that the characteristics of early childhood must be considered and that a developmental continuum of standards, curriculum and assessments would better support the transitions of young children from the early years into later schooling.

In reading a joint position statement of NAEYC and NCTM, which was adopted in 2002 and updated in 2010, it appears that there is indeed much work to be done prior to the implementation of the Common Core. The position statement argues that to support high quality mathematics education, institutions, program developers, and policy makers should:

a. create more effective early childhood teacher preparation and continuing professional development;

b. use collaborative processes to develop alignment of appropriate high-quality standards, curriculum and assessment;

c. design structures and policies that support ongoing teacher learning, teamwork and planning; and

d. provide resources to overcome barriers to young children's proficiencies at mathematics at the classroom, community, institutional and system-wide levels (NAEYC and NCTM 2010).

The position statement supports that high-quality, challenging and accessible mathematics is a fundamental foundation to future mathematics learning (NAEYC 2009). According to Bredekamp (2004), the challenges of such a task, especially for young children, are to ensure that:

- innovation is not stifled;

- children are not put into inappropriate categories;

- individual or cultural differences are not ignored;

- the end result is not a narrow, superficial teaching that fails to give children a solid foundation.

\section{More Time is Needed}

Mathis (2010) recommends that:

a. the initiative continue, but that it take the form of a low stakes advisory and assistance tool for the states as a way of improving curriculum and professional development;

b. Common Core standards be subjected to extensive validation, trials and revisions before they are implemented thus allowing for careful examination and experimentation by school-based practitioners; and

c. Policymakers not implement high stakes accountability when the assessments used to measure such accountability are inadequate.

These recommendations are sound and, if considered, would allow states and in turn local districts to have time to improve curriculum and professional development opportunities for teachers in mathematics while the Common Core standards themselves are subjected to scientifically-based research. Assessments would be able to be properly developed that are aligned with the standards and would also be subjected to the same time of scientific scrutiny as the standards themselves prior to being used for high stakes purposes.

\section{Recommendations}

Given the swiftness of the initiative, it would be wise to use caution when moving forward with the common core standards as written. Cooperation, collaboration and professional development is needed before we experiment with our children. In considering the Common Core Standards as a working draft, educators would then have the opportunity to develop curriculum, assessments and professional development that would allow for the initiative to progress, albeit at a slower pace. Our youngest learners deserve the most scrutiny as they seem to have the most to lose should this initiative fail. The pace is too swift and the details of the expectations for our youngest students are not being carefully linked with the research. I would urge early childhood educators to read the standards carefully and engage in a national conversation prior to implementation of the Common Core Mathematics Standards.

\section{References}

Bredekamp, S. (2004). Standards for preschool and kindergarten mathematics education. In D. H. Clements, J. Sarama, \& A. M. DiBiase (Eds.), Engaging young children in mathematics: standards for early childhood mathematics education (pp. 77-82). Mahwah, NJ: Lawrence Erlbaum.

Carmichael, S. B., Martino, G., Porter-Magee, K., Wilson, W. S., Fairchild, D., Haydel, E., Senechal, D., \& Winkler, A. M. (2010). The state of the state standards and the common core2010. Washington: Thomas B. Fordham Institute. Retrieved from http://edexcellence.net/index.cfm/news_the-state-of-state-standardsand-the-common-core-in-2010. 
Council of Chief State School Officers \& National Governors Association Center for Best Practices. (2010). Common core state standards for mathematics. Common Core State Standards Initiative. Retreived from http://www.corestandards.org/assets/ CCSSI_Math\%20Standards.pdf.

Council of Chief State School Officers \& National Governors Association Center for Best Practices.(2010). Introduction to the common core state standards. Common Core State Standards Initiative. Retreived from http://www.corestandards.org/assets/ ccssi-introduction.pdf.

Council of Chief State School Officers \& National Governors Association Center for Best Practices. (2010). Introduction. Standards for mathematical practice. Common Core State Standards Initiative. Retreived from www.corestandards.org/thestandards/mathematics/introduction/standards-for-mathematicalpractice.

Darling-Hammond, L. (2010). The flat world and education: How America's commitment to equity will determine our future. New York, NY: Teachers College Press.

Gewertz, C. (2010, June 9). Allies shift focus toward promoting standards adoption. Education Week, 29(33), 1, 18-19.

Kohn, A. (2010, January 14). Debunking the case for national standards: One size fits all mandates and their dangers. Retrieved from http://www.alfiekohn.org/teaching/edweek/national. htm.

Mathis, W. J. (2010). The "common core" standards initiative: An effective reform tool? Boulder and Tempe: Education and the Public Interest Center \& Education Policy Research Unit. Retrieved from http://epicpolicy.org/publication/common-corestandards.

McCluskey, N. (2010, February 17). Behind the curtain: Assessing the case for national curriculum standards. Washington: CATO Foundation, policy analysis 66. Retrieved from http://www.cato. org/pub_display.php?pub_id=11217.

Milgram, R. J. (2010). Review of final draft core standards. Testimony to the California Academic Content Standards Commission. Retrieved from http://concernedabouteducation. posterous.com/review-of-common-core-math-standards.

Munson, L. (2011). What students really need to learn: Topperforming nations set their instructional sights on far more than basic reading and math skills. Educational Leadership, 68(6), 10-14.

National Association for the Education of Young Children. (2009). Developmentally appropriate practice in early childhood programs serving children from birth through age 8. Washington:
National Association for the Education of Young Children. Retrieved from http://www.naeyc.org/files/naeyc/file/positions/ PSDAP.pdf.

National Association for the Education of Young Children \& National Association of Early Childhood Specialists in State Departments of Education. (2002). Early learning standards: Creating the conditions for success. Washington: National Association for the Education of Young Children. Retrieved from http://www.naeyc. org/files/naeyc/file/positions/position_statement.pdf.

National Association for the Education of Young Children \& National Association of Early Childhood Specialists in State Departments of Education. (2010). Joint statement of the National Association for the Education of Young Children and the National Association of the Early Childhood Specialists in State Departments of Education on the common core standards initiative related to kindergarten through third grade. Washington: National Association for the Education of Young Children. Retrieved from http://www.naeyc.org/files/naeyc/file/policy/NAEYC-NAECSSDE-Core-Standards-Statement.pdf.

National Association for the Education of Young Children \& National Council of Teachers of Mathematics. (2010). Early childhood mathematics: Promoting good beginnings. Washington: National Association for the Education of Young Children. Retrieved from http://www.naeyc.org/files/naeyc/file/positions/psmath.pdf.

National Council of Teachers of Mathematics. (2010). NCTM public comments on the common core standards for mathematics. Retrieved from http://www.nctm.org/about/content.aspx?id=25 186.

Phillips, V., \& Wong, C. (2010). Tying together the common core of standards, instruction and assessment. Phi Delta Kappan, 91(5), $37-42$.

Ravitch, D. (2010). The death and life of the great American school system. New York, NY: Basic Books.

Reys, B., \& Lappan, G. (2007). Consensus or confusion? The intended math curriculum in state-level standards. Phi Delta Kappan, 88(9), 676-680.

Western Australian Minister for Education. (2006). First steps in mathematics volume 1: Understand whole and decimal numbers, understand fractional numbers. Beverly, MA: STEPS Professional Development.

Whitehurst, G, (2009, October 14). Don't forget curriculum. Providence: Brown Center Letters on Education, \#3. Retrieved February 11, 2010, from http://www.brookings.edu/papers/2009/ 1014_curriculum_whitehurst.aspx. 